\begin{tabular}{|l|l|l||}
\hline \multicolumn{2}{|c|}{ PublisherInfo } \\
\hline \hline PublisherName & $:$ & BioMed Central \\
\hline \hline PublisherLocation & $:$ & London \\
\hline \hline PublisherImprintName & $:$ & BioMed Central \\
\hline \hline
\end{tabular}

Key players in yeast sporulation

\begin{tabular}{|l|l|l||}
\hline \multicolumn{2}{|c|}{ ArticleInfo } \\
\hline \hline ArticleID & $:$ & 3907 \\
\hline \hline ArticleDOI & $:$ & $10.1186 /$ gb-2001-2-2-reports0003 \\
\hline \hline ArticleCitationID & $:$ & reports0003 \\
\hline \hline ArticleSequenceNumber & $:$ & 16 \\
\hline \hline ArticleCategory & $:$ & Paper report \\
\hline \hline ArticleFirstPage & $:$ & 1 \\
\hline \hline ArticleLastPage & $:$ & 3 \\
\hline \hline & & RegistrationDate : 2000-12-28 \\
ArticleHistory & $:$ & Received \\
& $:$ 2000-12-28 \\
\hline \hline ArticleCopyright & $:$ & BioMed Central Ltd2001 \\
\hline \hline ArticleGrants & $:$ & \\
\hline \hline
\end{tabular}




\begin{tabular}{|l|l|l|}
\hline ArticleContext & $:$ & 130592222 \\
\hline
\end{tabular}

\section{Rachel Brem}

\section{Abstract}

Expression arrays have been used to detect mRNAs regulated during sporulation in two strains of Saccharomyces cerevisiae.

\section{Significance and context}

The meiotic formation of spores in yeast is a well-defined biochemical model for gene regulation. Many of the genes involved in the sporulation system have already been characterized. Primig et al. surveyed the mRNA expression patterns of all yeast genes through the sporulation time course with the aim of finding new players in sporulation.

\section{Key results}

Primig et al. made use of W303 and SK1, two strains of budding yeast with different sporulation efficiencies. The authors measured mRNA levels of all genes in W303 and SK1, at one- or two-hour timepoints throughout sporulation. The authors looked for genes whose expression levels fluctuated during sporulation by at least 4-fold in SK1 and at least 2.5-fold in W303. The 915 genes that meet these empirical criteria are called by Primig et al. 'core meiotic genes'. They are candidates for general players in meiosis, as elements controlling strain-specific meiotic behaviors are weeded out by the selection method. As a control, Primig et al. measured expression changes of all genes over time in starved, nonsporulating variants of W303 and SK1. Of the 915 core genes, an unreported fraction appear regulated in one control, and $5 \%$ appear regulated in both controls.

Clustering analysis was performed on mRNA expression data of all SK1 genes whose expression fluctuated during sporulation. The result of this calculation was a set of clusters of genes. All the genes within each cluster have similar expression patterns over time. The SK1 clusters can be empirically rationalized on the basis of known protein functions. But are they general across yeast strains? Primig et $a l$. addressed this question indirectly by making a graph for each of the 915 core genes which plots mRNA levels over time from the isotype in SK1 against those from the isotype in W303. The correlation coefficient of $60 \%$ of these graphs is over 0.8 . Thus, only $60 \%$ of core genes follow the same temporal pattern in the two yeast strains. This implies that the clustering from the SK1 strain is generally useful for only $60 \%$ of core genes. 


\section{Links}

Data from this study is available at Rochelle E. Esposito's lab and the Meiosis database.

\section{Conclusions}

Primig et al. conclude that a fraction of their 915 core genes are likely to be key players in meiosis, and that their cluster designations may spur new models of regulation in meiosis.

\section{Reporter's comments}

The strength of this paper lies in the identification of 915 core genes. These could be useful starting points for biochemical studies of sporulation. The paper's weakness is in its controls, which appear quite powerful but may not be used to their full potential. For example, in evaluating the 915 core genes, one would like to know how many were true false positives, that is, they appeared to be regulated in one non-sporulating control strain. Also, to judge the clusters of expression patterns, one needs some statistical framework. The average expression pattern across the genes in a cluster is noisy, and the average between two yeast strains is noisier still; quantitative comparison with controls would be helpful here.

\section{Table of links}

Nature Genetics

Rochelle E. Esposito's lab

Meiosis database

\section{References}

1. Primig M, Williams RM, Winzeler EA, Tevzadze GG, Conway AR, Hwang SY, Davis RW, Esposito RE: The core meiotic transcriptome in budding yeasts. Nat Genet. 2000, 26: 415-423. 1061-4036 